\title{
Render unto Darwin
}

\section{Gregory A Petsko}

Address: Rosenstiel Basic Medical Sciences Research Center, Brandeis University, Waltham, MA 02454-9110, USA.

Email: petsko@brandeis.edu

Published: I June 2009

Genome Biology 2009, 10:106 (doi:10.1186/gb-2009-10-5-106)

The electronic version of this article is the complete one and can be

found online at http://genomebiology.com/2009//0/5/106

(c) 2009 BioMed Central Ltd

You probably haven't encountered a website for something called BioLogos. If you have, you will undoubtedly already have formed a strong opinion about it - it's that kind of site. If you haven't, you really ought to check it out [http://www.biologos.org]. It's the website for something called the BioLogos Foundation. According to its mission statement, "The BioLogos Foundation promotes the search for truth in both the natural and spiritual realms seeking harmony between these different perspectives." The foundation was established by Francis Collins with a grant from the John Templeton Foundation, a much older organization with a similar mission. And that, apart from its intrinsic interest, is why you should check it out, and why I'm wagering you will have strong opinions when you do. Francis Collins is the scientist who headed the publicly funded Human Genome Sequencing Project in the 1990 s. Until last August he was the head of the National Human Genome Institute at the National Institutes of Health (NIH), which continues that work and funds much of the genome biology in the United States. And he just might be the next director of the NIH, the largest scientific research funding organization in the world.

In a public statement, Collins said that he established the BioLogos Foundation "to address the escalating culture war between science and faith in the United States. On one end of the spectrum, 'new atheists' argue that science removes the need for God. On the other end, religious fundamentalists argue that the Bible requires us to reject much of modern science. Many people - including scientists and believers in God - do not find these extreme options attractive. BioLogos represents the harmony of science and faith. It addresses the central themes of science and religion and emphasizes the compatibility of Christian faith with scientific discoveries about the origins of the universe and life. To communicate this message to the general public and add to the ongoing dialog, The BioLogos Foundation created BioLogos.org."

Let's dissect this statement, because if ever there was a statement that needed dissecting, this is one. I completely agree with Collins that there is a culture war between science and faith in the United States. But I do not agree that the war is due primarily to the clash between the extremists on both sides. Take the "new atheists", for example. There are many atheists in the United States, and some of them are scientists. But only a handful would take the extreme - and, to my mind, incorrect - position that science disproves the existence of God. The British scientist Richard Dawkins might, but he doesn't speak for the majority of scientists I know, and his eloquent but strident voice has only served to inflame the opposition by preaching to the converted. There are many more agnostics, who simply believe that there is no compelling evidence to believe in any deity.

Now let's look at that opposition, the "religious fundamentalists" who argue that "the Bible requires us to reject much of modern science". There are a lot more of those, especially in the United States, but - and this is a crucial distinction, as we shall see - they are almost entirely evangelical Christians, not "religious fundamentalists" in general. Evangelical Christians often take the Bible literally, and a literal reading of the Bible is certainly incompatible with many of the findings of science.

One of the missions of the BioLogos website is to advance the idea of theistic evolution, a concept discussed in depth in Collins' book The Language of God, which is also promoted on biologos.org. Essentially, theistic evolution means that evolution is the way God created life. I was first clued into this website by Jonathan Eisen, an evolutionary biologist and open access publishing maven at the University of California, Davis. Eisen, whose blog The Tree of Life [http://phylogenomics.blogspot.com/] is a delightful and thoughtful commentary on the worlds of both genomics and scientific publishing, wrote about BioLogos on 5 May. So that you will know where he's coming from, here's his opening statement: "I am all for trying to have discussions about science and religion. But I do not think the two topics are really compatible in the sense of merging them together. Science (and medicine) should be about, well, science. And 
religion can be about whatever it wants to be. And when we can get religious and scientific leaders together to talk about the implications of each area on the other and on the world, fine too. But merging the two together into one hybrid such as Christian Science and Creation Science? Not for me.”

He goes on to make a pointed criticism of the underlying logic - or lack thereof, in his view - behind BioLogos. "The details of Collins' attempt to merge science and religion into a version of theistic evolution are really unclean. Basically, he is trying to argue that on the one hand science and religion are completely separate activities (I support this) but at the same time argues that God can intervene in the setting up of natural laws and in providing some guidance here and there in order to, for example, produce human beings in his image. The website repeats some things from Collins' book that are equally illogical - such as saying that altruism can be explained by science (and even specifically saying that science is the way to explain the natural world) but then turning around and saying that science cannot explain extreme forms of altruism (and therefore implying that actually, the natural world cannot be explained by science). Which is it? Is science for the natural world or not?" Eisen is right that this, and some of BioLogos' other talking points, smack of setting up a straw man.

But in the end, BioLogos aims to show that the findings of science are not inconsistent with the existence of God. And not just any God. BioLogos is all about the Christian God. It even says so: "The creation story of BioLogos is compatible with many faith traditions, and there is no way to give a scientific proof for one monotheistic faith over another. Therefore, this response will simply show the compatibility of Christianity with BioLogos.” And again, more forcefully, in their mission statement: "the website is a reliable source of scholarly thought on contemporary issues in science and faith that highlights the compatibility of modern science with traditional Christian beliefs."

Here's another example: "For believers, these [scientific] discoveries must ultimately be compatible with the truth that is revealed in the Bible, and it is the conviction of BioLogos that this compatibility is not only desirable but also possible. The limitation is that our access to all forms of truth, including scientific and religious, is at best partial." The statement that it is Biblical truth that science must be compatible with (and there are other comments that make it clear BioLogos means the Christian Bible, especially the New Testament) marks a clear attempt to link science with one brand of religion.

The creators of BioLogos have every right to make the foundation and website about whatever they want. And I suppose you could argue that, as I see it, because it is evangelical Christians that are the chief opponents of modern science, especially evolution, it is sensible for scientists to promote the compatibility of science with Christian beliefs. But I don't agree. I think it's a huge mistake.

GK Chesterton, a devout Roman Catholic, has his priestdetective Father Brown say, in the superb short story The Sign of the Broken Sword, "When will people understand that it is useless for a man to read his Bible unless he also reads everybody else's Bible? A printer reads the Bible for misprints. A Mormon reads his Bible and finds polygamy; a Christian Scientist reads his and finds we have no arms and legs." I've always liked this quotation, and not just because I agree that one huge problem with putting your faith in the literal reading of a book is that you can find justification in that book for almost any form of behavior, from altruism to genocide to slavery. I like it for a reason that Chesterton probably never intended: it reminds me that there are many more religions than Christianity, and many more people of faith than monotheists. I think if you are going to understand people of faith and try to see how we as scientists can find common ground with them, it is discriminatory - and possibly something worse - to focus on Christians or even monotheists (which, in the modern world, pretty much consists of Muslims, Christians and Jews - Zoroastrians being in short supply nowadays - and I'm pretty sure that the BioLogos folks would not include Islam in their mission, given that faith's denial of the divinity of Christ). If you are going to read the Christian Bible you should also read the Jewish Bible. And the Book of Mormon. And the Koran. And the Bhagavad Gita. If you really care about making contact with people of faith you should not exclude most of them just because they worship different gods from yours.

In some temples in India, during services the priest will read from the Hebrew or Christian Bible and the Muslim Koran as well as the Hindu Gita, moving from one to the other as though it did not matter what precise words were being spoken as long as there was something greater than the individual self that was being worshipped. How can we as scientists find common ground with people of faith unless we recognize the commonalities they share with each other? At its best, all religion is about a love for the natural world, a desire to help other people, and a sense that life is well lived only when it is not lived selfishly and pettily - values that typically underlie most scientific research. At its worst, religion is about unquestionable certainty, authoritarianism, exclusion and discrimination - things that have no place in science either. Scientists can make common cause with people of faith through the values we share, but must reject the extremist, intolerant views that poison both spheres.

And in the end, that's my big problem with BioLogos - at its heart, it strikes me as implicitly exclusionary (plus I agree with Eisen that its logic is shaky). I would have much preferred a clearcut effort to emphasize the non-connectedness of science and faith: that science is about evidence and testable hypotheses, whereas religion is about believing in 
things for which there is no evidence whatsoever, and cannot be. That would place them in separate realms, but with common ground as I defined it above. The moment you start trying to say that data from science is compatible with the Christian religion in particular, you imply that, for example, polytheistic religions are wrong, and maybe not just as a matter of faith, but as a matter of science.

Nothing is more dangerous than such absolutism. It sets one type of religion as being true and therefore can be used to support the branding of all the others as false. However wellintentioned, BioLogos isn't likely to bring peace to the war between science and religion if it is oriented so strongly towards one religion.

I would have loved to see the resources that the Templeton and BioLogos Foundations spent on biologos.com - both financial and in terms of human effort - devoted to clarifying and promoting the distinctions between science and religion and to a search for a common ground that does not exclude anyone of faith. That's something I could support (and, I bet, something that Jonathan Eisen and possibly Charles Darwin could support, too). But the idea that science provides information that cannot be explained by science alone - and therefore that science 'needs' the Christian God for a complete description of the universe - strikes me as the wrong thing to do. Render unto Darwin the things that are Darwin's, and unto God the things that are God's. But for God's sake (or should that be Darwin's?), don't mix them together. 